\title{
Species density and shell morphology of gold ring cowry (Monetaria annulus, Linnaeus, 1758) (Mollusca: Gastropoda: Cypraeidae) in the coastal waters of Ambon Island, Indonesia
}

\author{
LOUVENSKA N. LATUPEIRISSA ${ }^{1, \vartheta}$, FREDY LEIWAKABESSY ${ }^{2}$, DOMINGGUS RUMAHLATU ${ }^{2, v v}$ \\ ${ }^{1}$ Postgraduate Program of Biology Education, Universitas Pattimura. Jl. Dr. Tamaela, Ambon 97116, Maluku, Indonesia. Tel./fax. +62-911-311803, \\ `email: louvenska11@gmail.com \\ ${ }^{2}$ Program of Biology Education, Faculty of Teacher Training and Education, Universitas Pattimura. J1. Ir. M. Putuhena, Ambon 97233, Maluku, \\ Indonesia. Tel./fax.: +62-911-3825216, "vemail: dominggus_amq@yahoo.co.id
}

Manuscript received: 29 January 2020. Revision accepted: 10 March 2020.

\begin{abstract}
Latupeirissa LN, Leiwakabessy F, Rumahlatu D. 2020. Species density and shell morphology of gold ring cowry (Monetaria annulus, Linnaeus, 1758) (Mollusca: Gastropoda: Cypraeidae) in the coastal waters of Ambon Island, Indonesia. Biodiversitas 21: 1391-1400. The purpose of this research was to examine environmental factors, species density, and the shell morphology of Monetaria annulus. The samples were collected by using the line transect method at 6 research stations. The data of the environmental factors (temperature, salinity, and $\mathrm{pH}$ of seawater) as well as species density of $M$. annulus were collected with in-situ technique, while the shell morphology of M. annulus was measured at Laboratory of the Deep-Sea Research Center, Indonesian Institute of Sciences (LIPI) Ambon. The results of the measurements of the environmental factors in the coastal waters of Ambon Island showed some fluctuations in the measurement values. The seawater temperature ranged between $29.78-30.05^{\circ} \mathrm{C}$, the salinity of seawater ranged from 32.12-32.33\%o, and the $\mathrm{pH}$ of the seawater ranged from 8.34-8.49. The density of $M$. annulus at the research stations from the highest to the lowest was at Tanjung Tiram station, Suli station, Seri station, Hutumuri station, Halong station, and Latuhalat station $\left(0.27>0.24>0.23>0.19>0.14>0.12 \mathrm{ind} / \mathrm{m}^{2}\right)$. The results of the measurement of the shell morphology showed many variations in the size and shape of the shell of M. annulus with a total number (N) of 294 individuals. The length, the width, and the height of the shell, the length of the blotches, the width of the blotches, and the total weight of $M$. annulus from each research station were significantly different $(p<0.005)$. These results indicate that the differences in the shell morphology of $M$. annulus at each research station were influenced by waves, the strength of the currents sea waves, and the different substrate of water. In addition, the variation of shell morphology can be a reason for characterization in the taxonomy of the Cypraeidae family.
\end{abstract}

Keywords: Density, environmental factors, Monetaria annulus, shell morphology, taxonomy

\section{INTRODUCTION}

Gastropods are one of the classes in mollusk phylum that are widely distributed in various aquatic ecosystems with number of species reaching 100.000 (Ruppert et al. 2004; Strong et al. 2008). There were 30 species found in Tanjung Jara, Terengganu beach, Peninsular Malaysia (Baharuddin et al. 2018), 11 species were found in Northeast Algeria (Belhiouani et al. 2019), 15 species were found in the mangrove ecosystem of Lubuk Kertang village, North Sumatra (Manullang et al. 2018), and 65 species were found in the waters of Ambon Island, Indonesia (Rumahlatu and Leiwakabessy 2017). In addition, the distribution of gastropods in aquatic ecosystems is influenced by environmental factors such as temperature, salinity, $\mathrm{pH}$, marine oxygen, organic matter content, and the composition of the substrate making up the waters (Pyron and Brown 2015; Dmitrović et al. 2016; Bula et al. 2017; Rumahlatu and Leiwakabessy 2017; Sahidin et al. 2018; Yunita et al. 2018).

One of gastropod species found in the coastal waters of Ambon Island is Cypraea annulus and commonly known as the Gold Ring Cowry (Laimeheriwa 2017; Laimeheriwa et al. 2018a, 2018b). In the classification system, $C$. annulus is also known as Monetaria annulus (Meyer 2003; WoRMS Editorial Board 2015). Tissot (1984) explained that the shell morphology of Monetaria annulus is smooth, slippery, having small spots and colorful. The high diversity of shell morphology is thought to be due to genetic, geographic, ecological and sexual dimorphism variations. To understand the evolution M. annulus, explanation for the mechanism and geographic variation of shell morphology of this species is necessary. Renaud's (1976) reported that different shell morphologies are influenced by different habitats. The shells of $M$. annulus can be prominently found in the substantial zone, whereas fine shells in the intertidal zone. This species is distributed from the tropics to the temperate regions, in the Indowestern Pacific and lives on rocky, muddy and sandy beaches at a depth of $2 \mathrm{~m}$ (Villamora and Yamamoto 2015).

The waters of Ambon Island, Indonesia, has a high potential of marine biological resources, because it has various types of marine life and diverse ecosystems, including coral reefs with various species of fish (Limmon et al. 2017; Limmon et al. 2018), seagrass (Irawan and Nganro 2016), sea urchins (Silahooy et al. 2013; Tuapattinaja et al. 2014; Setyastuti et al. 2018), and 
gastropods (Rumahlatu and Leiwakabessy 2017). Foin (1989) reported that different aquatic environments can affect the thickness of the shell of the genus Cypraeidae. Meanwhile, Irie (2006) also reported that macro and even micro geographical differences can affect the morphology of $M$. annulus shells. Therefore, a study of density and measurement of shell morphology can provide information on the taxonomy of the Cypraeidae family, which is to assist in the preparation of $M$. annulus species on phylogeny trees. The aims of this study were to determine the density and measure the morphology of $M$. annulus shells which includes the length, width and height of the shell; the length and width of the blotch, and the average weight of $M$. annulus at six different stations in Ambon Island waters.

\section{MATERIALS AND METHODS}

\section{Study site}

This study was conducted in April-May 2018 at the coordinate $3^{\circ} 37^{\prime} 56^{\prime \prime S}, \quad 128^{\circ} 18^{\prime} 30^{\prime \prime} \mathrm{E}$ to $3^{\circ} 47^{\prime} 38^{\prime \prime} \mathrm{S}$, $128^{\circ} 05^{\prime} 42^{\prime} \mathrm{E}$ in coastal waters of Ambon Island (i.e., Seri coast: station 1, Latuhalat coast: station 2, Halong coast: station 3, Tanjung Tiram coast: station 4, Suli coast: station 5, and Hutumuri coast: station 6) (Figure 1). These locations were determined as the study sites based on the preliminary observations of the appearance of M. annulus, because this species do not appear in all coastal on Ambon Island.

\section{Sampling procedure and laboratory}

The data of the environmental parameters (temperature, salinity, $\mathrm{pH}$ of seawater, and substrate) were determined using an in-situ sampling technique. Furthermore, the morphology of the shell of $M$. annulus was analyzed which covered the shell length (SL), shell width (SW), shell height $(\mathrm{SH})$, blotch length (BL), blotch width (BW), total weight (TW) and the species density of M. annulus. A preliminary study (observation) was carried out to determine the area in the coastal waters of Ambon Island, which contains M. annulus. The sampling locations were determined purposively based on the habitat of M. annulus. The data in the field were collected using the transect method following Rumahlatu and Leiwakabessy (2017), performed at the lowest ebb tide, beginning with the determination of the area of sampling, and then apply the vertical transect lines from the highest tide limit as many as 3 transect lines (towards the sea) with the distance between one and the other transect lines $50 \mathrm{~m}$. For each transect, 8 plots of $1 \mathrm{~m}^{2}$ were prepared. The distance between one plot and the other plots was $10 \mathrm{~m}$. Thus, the total transects at the six research stations were 24 transects with 144 plots.

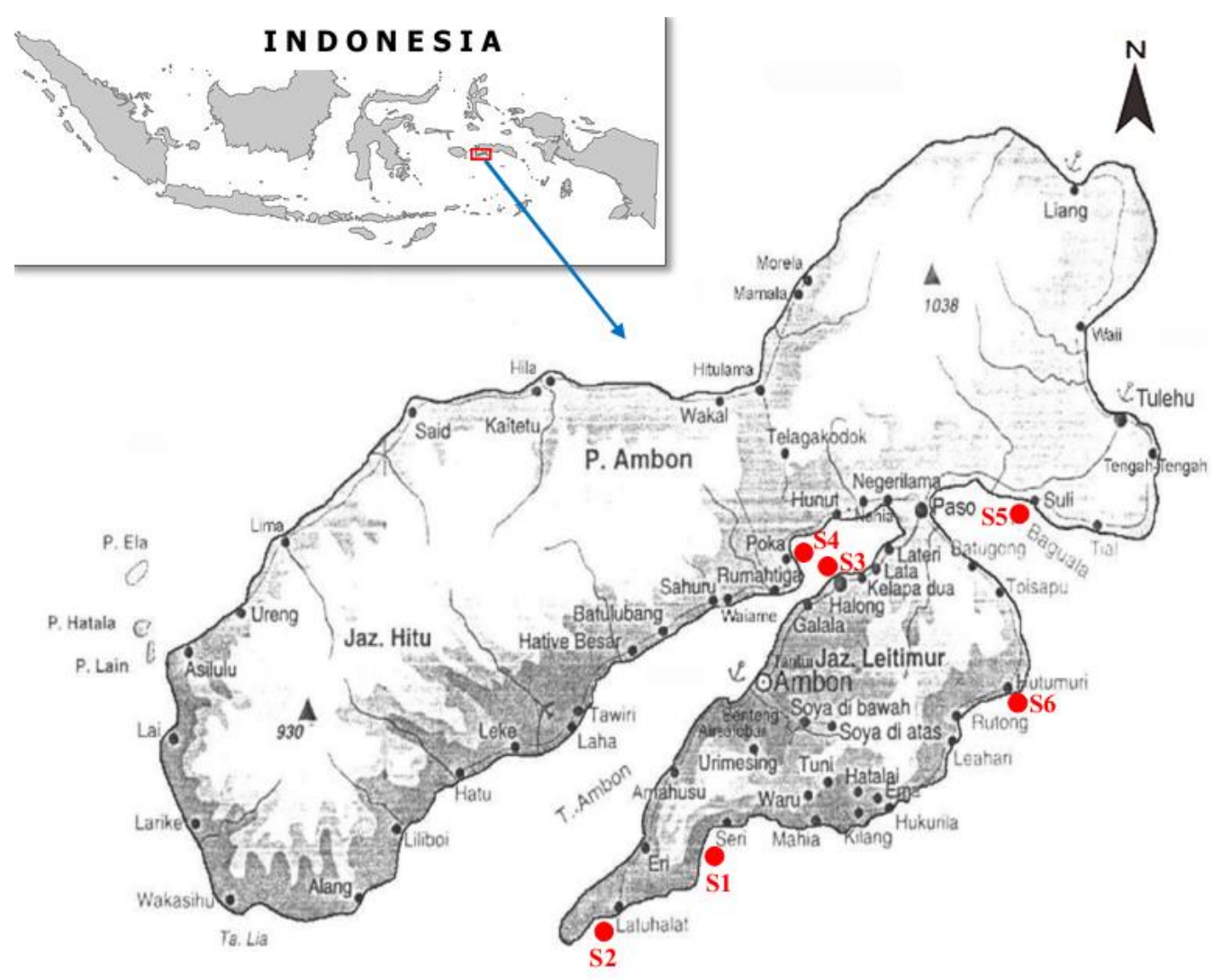

$1: 350,000$

AMBON ISLAND

Figure 1. Study sites of Monetaria annulus in Ambon Island, Maluku, Indonesia. Note: S = station. S1: Seri coast, S2: Latuhalat coast, S3: Halong coast, S4: Tanjung Tiram coast, S5: Suli coast, and S6: Hutumuri coast 


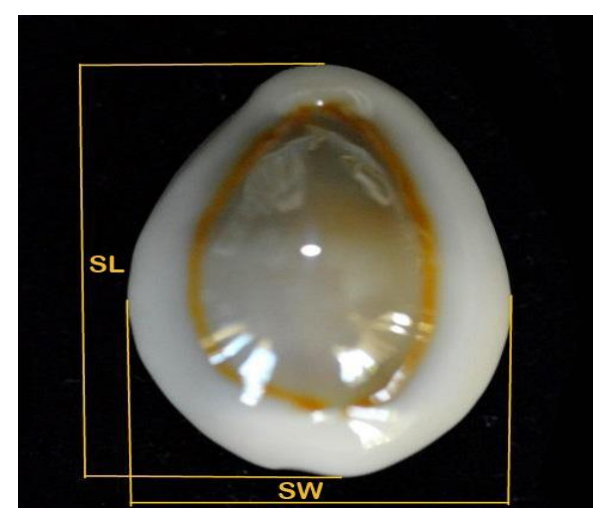

A

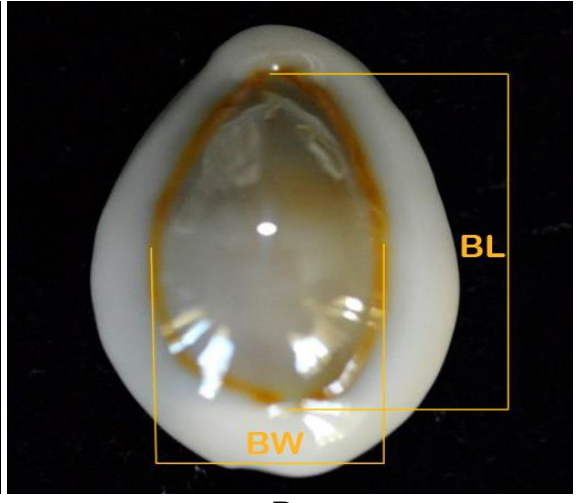

B

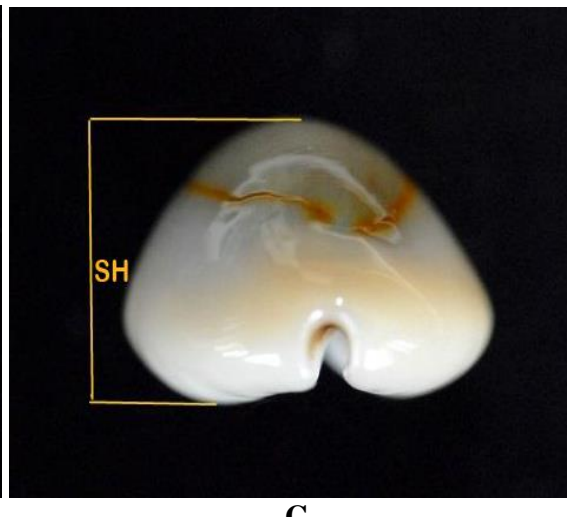

Figure 2. Parameter of the shell of Monetaria annulus morphology measurements

The measurements of the shell morphology of $M$. annulus were performed at the Laboratory of Deep-Sea Research Center, Indonesian Institute of Sciences (LIPI) Ambon. The morphology of were measured for shell length (SL), blotch length (BL) (Figure 2.A); shell width (SW) and blotch width (BW) (Figure 2.B); shell height (SH), (Figure 2.C) (Tissot 1984), while the total weight parameter (TW) was measured by weighing each individual of $M$. annulus.

\section{Data analysis}

The data on the environmental factors, species density of $M$. annulus, and the measurements of shell length (SL), shell width $(\mathrm{SW})$, shell height $(\mathrm{SH})$, blotch length (BL), blotch width (BW) and total weight (TW) were analyzed with descriptive approach. The species density of $M$. annulus was measured using the formula from Krebs (1989), as follows.

$$
\mathrm{D}=\mathrm{N} / \mathrm{S}
$$

Where:

D: Population density

$\mathrm{N}$ : Number of individuals

$\mathrm{S}:$ Unit area $\left(\mathrm{m}^{2}\right)$

The inferential statistics One-Way-ANOVA was used to analyze the differences in the shell morphology of $M$. annulus (shell length, shell width, shell height, blotch length, blotch width, and total weight) at each station in the waters of Ambon Island. The significant test was performed with LSD test (least significant difference), in case if the is significant difference in the inferential statistics results.

\section{RESULTS AND DISCUSSION}

\section{Conditions of Environmental Factors}

The results of the environmental factors (temperature, salinity, and $\mathrm{pH}$ ) measurement at six research stations in the waters of Ambon Island showed fluctuations in each for environmental factors (Table 1). The water temperature ranged between 29.78-30.05 ${ }^{\circ} \mathrm{C}$, which the highest temperature was found in Hutumuri station at $30.06^{\circ} \mathrm{C}$, while the lowest temperature was at Tanjung Tiram station at $29.78^{\circ} \mathrm{C}$. According to Rumahlatu and Leiwakabessy (2017), the water temperature of Ambon Island ranged between $27.30-31.40^{\circ} \mathrm{C}$. According to Rumahlatu and Huliselan (2016), the high temperature of the seawaters of Ambon Island is greatly influenced by the heat supply from the seabed, the decomposition of household waste, and intensity of sun penetration due to seasonal changes. Irie and Morimoto (2016) reported that the gastropods of the Cypraeidae class, Monetaria annulus experimentally experienced shell growth between $21^{\circ} \mathrm{C}$ and $34^{\circ} \mathrm{C}$. This condition is related to our current study (Table 1), which the temperature of seawater in the waters of Ambon has exceeded the range of temperature possible for $M$. annulus to live. However, M. annulus is still found in the waters of Ambon. This shows that $M$. annulus has adapted to high temperatures. This adaptation can be in the form of a change in behavior and habitat, where M. annulus tends to live in areas that are protected from sunlight such as coral reef, rockpool, seagrass leaves, and shelter under organicinorganic waste. Under these conditions, $M$. annulus is able to create a micro-climate suitable for life. In addition, $M$. annulus can develop other physiological adaptations such as the presence of protective proteins (chaperons) and increase the accumulation of hemoglobin and myoglobin, which affect the ability to survive in lack of oxygen condition (Portner et al. 2007; Calosi et al. 2013).

The seawater salinity in the observation sites is in the range between 31.12-32.33\%. The highest salinity was found in Seri station which was 32.33\%o, while the lowest salinity was found in Suli station at $31.12 \%$. The salinity of Ambon Island waters in the rainy season ranged between 29.00-30.00\% (Rumahlatu and Huliselan 2016), while in the dry season, salinity ranged between 32.01-32.02\%o (Rumahlatu and Leiwakabessy 2017). It means that the salinity of Ambon Island waters during the measurement was in the high range. According to Laimeheriwa (2017), salinity is one of the abiotic factors that greatly affect marine organisms including $M$. annulus in the osmoregulation process. Several types of research reported that the salinity values for the life of gastropods ( $M$. 
annulus) are varied. The suitable range of salinity for the life of $M$. annulus is reported between 33.67-34.97\%o (Hughes 2011), and 33.0-33.3\%o (Islami 2015). It is related to this study (Table 1), which the seawater salinity of Ambon Island waters was lower than the suitable range of salinity for the life of $M$. annulus. However, M. annulus was still found in Ambon Island waters. The low salinity value in this study was caused by the presence of freshwater input from rivers in the study location. According to Rumahlatu et al. (2008), the salinity of seawater is strongly influenced by the input of river flow that carries mineral salts from the mainland and the mass exchange of water from the ocean, namely the Banda Sea during the tide. Syuja et al. (2018) reported that mollusks are tolerant to salinity $30-32.67 \%$. This means that $M$. annulus has adapted to salinity values.

The results of the measurement of the seawater $\mathrm{pH}$ (Table 1) indicated that the $\mathrm{pH}$ of the seawater was in the range of 8.34-8.49. The highest $\mathrm{pH}$ was found in the Halong station, while the lowest $\mathrm{pH}$ was found in the Hutumuri station. Some researchers who conducted research in Ambon Island waters reported that the $\mathrm{pH}$ range of the waters was between 7.03-7.68 (Rumahlatu and Leiwakabessy 2017), 7.91-8.16 (Gemilang et al. 2017), 8.00-8.25 (Latuconsina et al. 2012). According to Gemilang et al (2017), terrestrial organic matter carried through rivers as well as the community activities has a significant effect on the $\mathrm{pH}$ values of the waters. The normal range of water $\mathrm{pH}$ is in the range 7.0-8.5 (Odum 1971). This means that the $\mathrm{pH}$ range of Ambon Island waters was very suitable for $M$. annulus to live.

\section{Density of Monetaria annulus}

The density of $M$. annulus at six research stations in the coastal waters of Ambon Island has fluctuated in the density value (Figure 3). The density of M. annulus from the highest to the lowest was Tanjung Tiram station, Suli station, Seri station, Hutumuri station, Halong station, and Latuhalat station $(0.27>0.24>0.23>0.19>0.14>0.12$ ind $/ \mathrm{m}^{2}$ ). The density of $M$. annulus at each research station different from each other. This was influenced by the different substrates of each station in the waters of Ambon Island, namely coral substrate (Ode 2014), coarse sand substrate, muddy sand substrate (Tuapattinaya and Rumahlatu 2019), rock and gravel substrate, coarse sand and mud substrate (Kho 2017). The highest density of $M$. annulus was at Tanjung Tiram station. This condition is due to the position of the station, which was in the Ambon Deep Bay area with the high availability of food (algae and other macrophytes). This was different from Latuhalat station, which was located in Ambon Outer Bay, where the area had a strong ocean current and the nutrient cycle is more complex, causing the availability of nutrients at this station to be less than that at the Tanjung Tiram station. The organisms having the highest density values indicate that these types of organisms have the ability to adapt to the environment they occupy so that they have high reproductive abilities (Amat et al. 2017). According to Rumahlatu and Leiwakabessy (2017), high diversity indicates the variation and density of an organism in marine waters.

On the other hand, the low density of $M$. annulus was caused by over-exploitation by people who used the shell of $M$. annulus as a traditional game tool, and the craft industry (shell-craft) (Poutiers 1998). Other factors affecting the density of $M$. annulus were extreme environmental factors (temperature, salinity, $\mathrm{pH}$ ). These environmental factors caused the difficulties for $M$. annulus adaptation to environmental changes. Human activities also can change environmental conditions, which caused a decrease in the density value and the abundance of gastropods, as well as other ectothermic species (Gallmetzer et al. 2017). This also happened in Ambon Island water (e.g. at Halong station), where the density of $M$. annulus was quite low. The low density of $M$. annulus was also influenced by the accumulation of heavy metals $\mathrm{Hg}, \mathrm{Cd}$ and $\mathrm{Pb}$ (Rumahlatu and Huliselan 2016; Rumahlatu et al. 2018; Rijal et al. 2014).

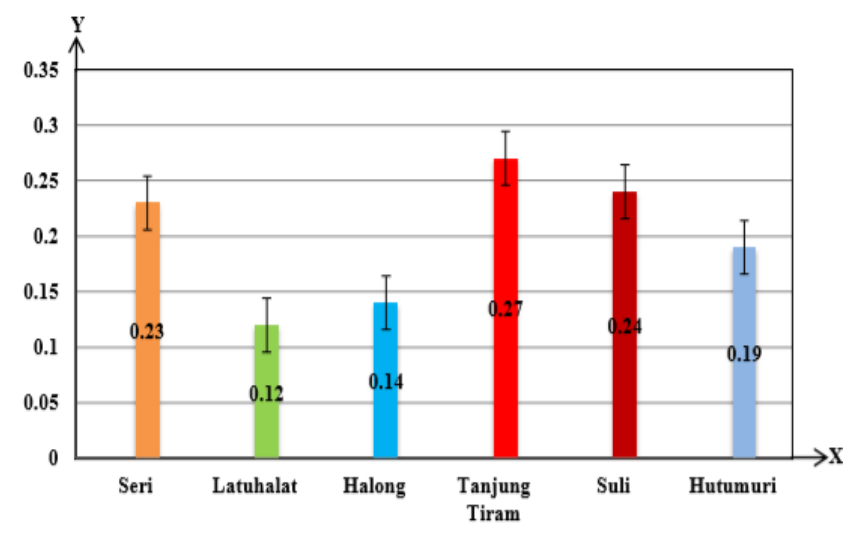

Figure 3. Density of Monetaria annulus in the coastal waters of Ambon Island, Maluku, Indonesia

Table 1. Physico-chemical condition (temperature, salinity, $\mathrm{pH}$, and substrate) in coastal waters of Ambon Island, Maluku, Indonesia

\begin{tabular}{|c|c|c|c|c|c|c|c|}
\hline \multirow{2}{*}{\multicolumn{2}{|c|}{ Station }} & \multicolumn{2}{|c|}{ Coordinate } & \multicolumn{4}{|c|}{ Physico-chemical parameters } \\
\hline & & Latitude & Longitude & Temperature $\left({ }^{\circ} \mathrm{C}\right)$ & Salinity (\%o) & pH & Substrate \\
\hline 1 & Seri & $3^{\circ} 45^{\prime} 01^{\prime \prime S}$ & $128^{\circ} 10^{\prime} 04^{\prime \prime} \mathrm{E}$ & 30.02 & 32.33 & 8.38 & Reef with Sand \\
\hline 2 & Latuhalat & $3^{\circ} 47^{\prime} 38^{\prime \prime S}$ & $128^{\circ} 05^{\prime} 42^{\prime \prime} \mathrm{E}$ & 30.01 & 32.32 & 8.37 & Reef with Sand \\
\hline 3 & Halong & $3^{\circ} 39^{\prime} 31$ ”s & $128^{\circ} 12^{\prime} 33^{\prime \prime E}$ & 29.80 & 31.13 & 8.49 & Muddy Sand \\
\hline 4 & Tanjung Tiram & $3^{\circ} 39^{\prime} 22^{\prime \prime} \mathrm{S}$ & $128^{\circ} 11^{\prime} 59^{\prime \prime} \mathrm{E}$ & 29.78 & 31.14 & 8.48 & Muddy Sand \\
\hline 5 & Suli & $3^{\circ} 37^{\prime} 56^{\prime \prime} \mathrm{S}$ & $128^{\circ} 18^{\prime} 30^{\prime \prime} \mathrm{E}$ & 30.04 & 31.12 & 8.47 & Gravel, Muddy Sand \\
\hline 6 & Hutumuri & $3^{\circ} 41^{\prime} 58^{\prime \prime} \mathrm{S}$ & $128^{\circ} 16^{\prime} 40^{\prime \prime} \mathrm{E}$ & 30.05 & 32.15 & 8.34 & Muddy Sand \\
\hline
\end{tabular}


Note: * Time of measurement: in the rainy season

Table 2. Matrix of the shell morphology of Monetaria annulus at each station in the coastal waters of Ambon Island, Maluku, Indonesia

\begin{tabular}{|c|c|c|c|c|c|c|c|c|}
\hline \multirow{2}{*}{\multicolumn{2}{|c|}{$\begin{array}{c}\text { Shell } \\
\text { morphology }\end{array}$}} & \multicolumn{6}{|c|}{ Stations } & \multirow{3}{*}{$\begin{array}{c}\text { Ambon Island } \\
294\end{array}$} \\
\hline & & \multirow{2}{*}{$\begin{array}{c}\text { Seri } \\
58\end{array}$} & \multirow{2}{*}{$\begin{array}{c}\text { Latuhalat } \\
31\end{array}$} & \multirow{2}{*}{$\begin{array}{c}\text { Halong } \\
34\end{array}$} & \multirow{2}{*}{$\begin{array}{c}\text { Tanjung Tiram } \\
65\end{array}$} & \multirow{2}{*}{$\begin{array}{c}\text { Suli } \\
60\end{array}$} & \multirow{2}{*}{$\begin{array}{c}\text { Hutumuri } \\
46\end{array}$} & \\
\hline SL & $\mathrm{N}$ & & & & & & & \\
\hline & $\bar{x}$ & 18.61 & 19.52 & 17.31 & 15.84 & 16.82 & 13.10 & 16.71 \\
\hline & Max & 23.74 & 22.81 & 23.18 & 21.36 & 20.82 & 17.35 & 23.74 \\
\hline & Min & 14.88 & 14.26 & 13.05 & 11.39 & 10.69 & 10.68 & 10.68 \\
\hline \multirow[t]{4}{*}{ SW } & $\mathrm{N}$ & 58 & 31 & 34 & 65 & 60 & 46 & 294 \\
\hline & $\bar{x}$ & 13.90 & 15.10 & 12.07 & 11.02 & 12.11 & 8.40 & 11.95 \\
\hline & Max & 18.23 & 18.24 & 18.59 & 14.99 & 15.40 & 11.72 & 18.59 \\
\hline & Min & 9.63 & 6.91 & 8.52 & 8.36 & 5.55 & 5.74 & 5.55 \\
\hline \multirow[t]{4}{*}{$\mathrm{SH}$} & $\mathrm{N}$ & 58 & 31 & 34 & 65 & 60 & 46 & 294 \\
\hline & $\bar{x}$ & 9.27 & 9.68 & 8.70 & 7.88 & 8.37 & 6.30 & 8.29 \\
\hline & Max & 12.13 & 11.43 & 11.25 & 11.33 & 10.31 & 10.41 & 12.13 \\
\hline & Min & 7.05 & 4.96 & 6.09 & 6.01 & 4.45 & 4.42 & 4.42 \\
\hline \multirow[t]{4}{*}{ BL } & $\mathrm{N}$ & 58 & 31 & 34 & 65 & 60 & 46 & 294 \\
\hline & $\bar{x}$ & 13.92 & 13.60 & 12.23 & 11.95 & 12.49 & 9.46 & 12,27 \\
\hline & $\operatorname{Max}$ & 17.88 & 18.18 & 18.74 & 17.50 & 17.75 & 14.18 & 18.74 \\
\hline & Min & 10.95 & 0.00 & 0.00 & 9.50 & 0.00 & 0.00 & 0.00 \\
\hline \multirow[t]{4}{*}{$\mathrm{BH}$} & $\mathrm{N}$ & 58 & 31 & 34 & 65 & 60 & 46 & 294 \\
\hline & $\bar{x}$ & 9.15 & 9.31 & 7.91 & 7.94 & 8.33 & 6.11 & 8.11 \\
\hline & Max & 12.26 & 12.28 & 11.71 & 12.16 & 11.70 & 9.37 & 12.28 \\
\hline & Min & 6.78 & 0.00 & 0.00 & 5.78 & 0.00 & 0.00 & 0.00 \\
\hline \multirow{4}{*}{ TW } & $\mathrm{N}$ & 58 & 31 & 34 & 65 & 60 & 46 & 294 \\
\hline & $\bar{x}$ & 2.48 & 3.00 & 1.64 & 1.26 & 1.73 & 0.72 & 1.74 \\
\hline & Max & 4.00 & 4.60 & 3.50 & 2.70 & 2.90 & 1.40 & 4.60 \\
\hline & Min & 0.90 & 0.30 & 0.20 & 0.10 & 0.20 & 0.20 & 0.10 \\
\hline
\end{tabular}

Note: $\mathrm{N}=$ Total number $(\mathrm{Ind}), \overline{\boldsymbol{x}}=$ Average of shell morphology $(\mathrm{mm})$, Max $=$ Maximum value of shell morphology $(\mathrm{mm})$, Min= Minimum Value of shell morphology (mm)

The morphology of the shell of Monetaria annulus (shell length, shell width, shell height, blotch length, blotch width and total weight) in the coastal waters of Ambon Island The shell morphology of Monetaria annulus

There are many variations for the size and shape of the shell of M. annulus in the waters of Ambon Island. The results of the measurement of the shell morphology of $M$. annulus (shell length (SL), shell width (SW), shell height $(\mathrm{SH})$, blotch length $(\mathrm{BL})$, blotch height $(\mathrm{BH})$ and total weight (TW)) showed that the total number (N) of $M$. annulus was as many as 294 individuals, with the highest number found in the Tanjung Tiram station (65 individuals), while the lowest number was found at Latuhalat station (31 individuals) (Table 2).

The shell length at the six research stations is shown that the highest average value was found at Latuhalat station with $19.52 \mathrm{~mm}$, while the lowest average value was found at Hutumuri station with $13.10 \mathrm{~mm}$, and the average value for the coast of Ambon Island was $16.71 \mathrm{~mm}$. In addition, the highest average value of shell width was found at Latuhalat station with $15.10 \mathrm{~mm}$, while the lowest average value at Hutumuri station with $8.40 \mathrm{~mm}$, and the average value of the shell width in the coastal waters of Ambon Island was $11.95 \mathrm{~mm}$. The highest average value of the shell height was found at Latuhalat station with 9.68 $\mathrm{mm}$, while the lowest average value was found at Hutumuri station with $6.30 \mathrm{~mm}$, and the average value of the shell height on the coastal waters of Ambon Island was $8.29 \mathrm{~mm}$ (Table 2).
The data of this research (Table 2) reveal that the length, width, and height of the shell of M. annulus at Latuhalat station were the largest of all, while the $M$. annulus at the Hutumuri station contained the smallest shell size of $M$. annulus. The length of the shell of $M$. annulus is largely determined by the waves and strong currents of sea waves (Tissot 1984), as well as the presence of pollutants in the waters (Primost et al. 2015). The characteristic size of the shell of $M$. annulus at Hutumuri station was relatively smaller than the shell size at the other stations. This might be caused by the adaptation to the sandy substrate environment (Sälgeback and Esavazzi 2006; Vermeij 2017; Yamamori and Kato 2018). The relatively small body size of the $M$. annulus living in the sandy substrate is probably helped the $M$. annulus for camouflage and survives from the predators or humans. In addition, the substrate at the Latuhalat and Seri stations was in the form of coral reefs. This caused $M$. annulus with large size to have more possibilities to survive. Large body size allows the $M$. annulus to camouflage with the corals as its life substrate, so the predators cannot easily detect the presence of $M$. annulus. This species also will tend to adapt its color and lifestyle with the substrate or its habitat (Troscianko et al. 2013). The size of the shell of $M$. annulus is also influenced by the geographical location and physical factors of the waters (Tissot 1984; Stafford et al. 2015; Saleky et al. 2016). Both Seri and Latuhalat stations were located at the Outer Ambon Bay, so the M. annulus in this location had a similar ratio of shell length and shell width. 
The shape of the shell of M. annulus was more globular than that of the $M$. annulus at the other stations. At the geographical conditions with open area waters, the shape of the gastropod shells will be more globular than the shells found in semi-open areas or in protected areas (Trussell 1997; Verhaegen et al. 2019). This condition plays a role to reduce the strength of current and ocean waves so that the $M$. annulus does not easily come off the substrate.

In addition, the blotch length at the six research stations (Table 2) has the highest average value at the Seri station with $13.92 \mathrm{~mm}$, while the lowest average value was at the Hutumuri station with $9.46 \mathrm{~mm}$. The blotch width dimension at the six research stations (Table 2) have the highest average value at the Latuhalat station with 9.31 $\mathrm{mm}$, and the lowest average value at the Hutumuri station with $6.11 \mathrm{~mm}$. The total weight at the six research stations (Table 2) showed that the highest average value was found at the Latuhalat station with $2.48 \mathrm{~g}$ while the lowest value was found at the Latuhalat station with $3.00 \mathrm{~g}$ while the lowest average value was found at Hutumuri station with $0.72 \mathrm{~g}$.

Blotches are a circular ring-shaped structure on the shell of M. annulus, which are used as a growth parameter for $M$. annulus and the diagnostic character of the Cypreadea group (Renaud 1976; Laimeheriwa 2017). The largest blotch length (BL) and blotch width (BW) (Table 2) were found at Seri station and Latuhalat station, with the blotch length $(13.92,13.60)$, and blotch width $(9.15,9.31)$. The smallest blotch was found at the Hutumuri station with the length and width was 9.46 and 9.37 , respectively. The relatively small size of the blotches at Hutumuri station was caused by the relatively small size of the shell of $M$. annulus at this station. Laimeheriwa (2017) explains that the blotch starts to appear when $M$. annulus is at the development stage of almost adult (sub-adult) with a shell size of about 15.00-18.99 mm. This was different from the results found in the study site. At the Hutumuri station, $M$. annulus was found with relative smaller size shells, and already had blotches. The results of this study indicate that the size of the blotches depends on the size of the shells, but the size of the shells of $M$. annulus is also determined by other environmental factors such as substrate, habitat, $\mathrm{pH}$, water depth (Chiu et al. 2003), velocity of ocean currents (Trussell 1997; Minton et al. 2008), predatory and population density (Crowl and Schnell 1990). This means that in this study, the size of the shell was influenced by the substrate where $M$. annulus lived. It can be concluded that the shell weight of $M$. annulus is largely determined by the length, width, and height of the shell (SL, SW, SH). The weight of the shell tends to follow the trend from SL, SW, $\mathrm{SH}$ measurements found at Latuhalat and Seri stations. The size of SL, SW, SH of M. annulus is larger than the size found at the other stations. This condition may also tend to have a higher shell weight, whereas the size of the SL, SW, and $\mathrm{SH}$ found at Hutumuri station is smaller because the weight of the shell is also smaller than at the other stations.

\section{Difference in length, width, and height of shell, blotch} length and width of Monetaria annulus

The results of the statistical analysis (ANOVA) on the shell length, shell width, shell height, blotch length, blotch width, and total weight of M. annulus (Table 3) are shown the significance value was 0.000 , which was smaller than the $\alpha 0.05(\mathrm{p}<0.05)$. It means that there was a difference in the shell length, shell width, shell height, blotch length, blotch width, and total weight of $M$. annulus at the six research stations in the coastal waters of Ambon Island. Furthermore, since the results of the One-Way-ANOVA showed a very significant effect, 0.05 LSD test was performed (Tables 4, 5, 6, 7, 8 and 9), which revealed the differences in the average of the shell length, shell width, shell height, blotch length, blotch width, and total weight of $M$. annulus at six observation stations in the coastal waters of Ambon Island.

The size of the length, width, and height of the gastropod shell are the main indicators to determine its growth and development (Tissot 1984; Chiu et al. 2002; Medeiros et al. 2015). The results of the analysis of OneWay-ANOVA (Tabel 3) is shown the average of length, width, and height of the shell of $M$. annulus from each of the stations was significantly different $(\mathrm{p}<0.05)$. LSD test results showed that the average length and width of $M$. annulus shells were significant at Hutumuri, Tanjung Tiram, Seri and Latuhalat stations, while Halong and Suli stations were not significant (Table 4 and Table 5). The average height of $M$. annulus shells was significant at all six stations, but the average height of shells was not significant at Tanjung Tiram and Suli, Suli and Halong, Seri and Latuhalat stations (Table 6). This insignificant difference was likely due to the geographical and environmental conditions of the stations which were relatively similar (Gustafson et al. 2014; Márquez et al. 2015). On the other hand, the main difference in the length and the width of the shell of M. annulus (Table 4 and Table 5) was influenced by the differences in habitat, predators, anthropogenic activity, and geographical conditions of each station (Tissot 1984; Chiu et al. 2002; Quensen and Woodruff 2003; Bourdeau et al. 2015; Rosin et al. 2018).

The length and the width of the shell of M. annulus in the Halong station and Suli station were not significantly different because of the protected environmental conditions and the relatively similar physical-chemical factors (currents and $\mathrm{pH}$ ). For the morphology of M. annulus shell height, the results of the analysis showed that the height of $M$. annulus shell at Tanjung Tiram and Suli stations; Halong and Suli; Seri and Latuhalat are not significant. Although, Tanjung Tiram, Halong and Suli stations are in different geographical locations, namely Ambon Bay and Baguala, they have the same coast topography and substrate types. While the Seri and Latuhalat coast is in the outer bay of Ambon, have the same substrate coast topography. These relatively protected conditions cause the sizes of the length, width, and height of the shell of $M$. annulus to be relatively similar. The same environmental conditions and geographical locations made the shells of gastropods have the same structure and shape (Trussell 1997; Tissot 1984; Cazenave and Zanatta 2016; Zhao et al. 2019). In addition, variations of the shapes of gastropods shells are influenced by the body size and the sex differences (Avaca et al. 2013). 
Table 3. The results of the one-way-ANOVA on the shell morphology of Monetaria annulus

\begin{tabular}{|c|c|c|c|c|c|c|}
\hline $\begin{array}{c}\text { Shell } \\
\text { Morphology }\end{array}$ & $\begin{array}{l}\text { Source of } \\
\text { variance }\end{array}$ & Sum of Squares & df & Mean Square & $\mathbf{F}$ & Sig. \\
\hline \multirow[t]{3}{*}{ SL } & Between Groups & 1114.931 & 5 & 222.986 & 50.063 & .000 \\
\hline & Within Groups & 1282.794 & 288 & 4.454 & & \\
\hline & Total & 2397.725 & 293 & & & \\
\hline \multirow[t]{3}{*}{ LW } & Between Groups & 1165.544 & 5 & 233.109 & 74.431 & .000 \\
\hline & Within Groups & 901.981 & 288 & 3.132 & & \\
\hline & Total & 2067.525 & 293 & & & \\
\hline \multirow[t]{3}{*}{ SH } & Between Groups & 295.309 & 5 & 59.062 & 34.680 & .000 \\
\hline & Within Groups & 490.478 & 288 & 1.703 & & \\
\hline & Total & 785.787 & 293 & & & \\
\hline \multirow[t]{3}{*}{$\mathrm{BL}$} & Between Groups & 585.038 & 5 & 117.008 & 10.461 & .000 \\
\hline & Within Groups & 3221.423 & 288 & 11.185 & & \\
\hline & Total & 3806.461 & 293 & & & \\
\hline \multirow[t]{3}{*}{ BW } & Between Groups & 297.641 & 5 & 59.528 & 12.307 & .000 \\
\hline & Within Groups & 1393.058 & 288 & 4.837 & & \\
\hline & Total & 1690.699 & 293 & & & \\
\hline \multirow[t]{3}{*}{ TW } & Between Groups & 144.269 & 5 & 28.854 & 76.470 & .000 \\
\hline & Within Groups & 108.669 & 288 & .377 & & \\
\hline & Total & 252.938 & 293 & & & \\
\hline
\end{tabular}

Table 4. Results of the LSD test on the differences in the shell length of Monetaria annulus

\begin{tabular}{lll}
\hline Station & Average & Notasi \\
\hline Hutumuri & 13.1065 & $\mathrm{a}$ \\
Tanjung Tiram & 15.8406 & $\mathrm{~b}$ \\
Suli & 16.8248 & \multicolumn{2}{c}{$\mathrm{c}$} \\
Halong & 17.3141 & \multicolumn{2}{c}{$\mathrm{c}$} \\
Seri & 18.6140 & \multicolumn{2}{c}{$\mathrm{e}$} \\
Latuhalat & 19.5216 & \multicolumn{2}{c}{} \\
\hline
\end{tabular}

Table 5. The results of the LSD test on the differences in the shell width of Monetaria annulus

\begin{tabular}{|c|c|c|c|c|c|}
\hline Station & Average & Notasi & Station & Average & Notasi \\
\hline Hutumuri & 8.4048 & $\mathrm{a}$ & Hutumuri & 6.1113 & $\mathrm{a}$ \\
\hline Tanjung Tiram & 11.0275 & $\mathrm{~b}$ & Tanjung Tiram & 7.9194 & $\mathrm{~b}$ \\
\hline Halong & 12.0735 & $\mathrm{c}$ & Suli & 7.9488 & $\mathrm{~b}$ \\
\hline Suli & 12.1100 & $\mathrm{c}$ & Halong & 8.3390 & $\mathrm{bc}$ \\
\hline Seri & 13.9000 & d & Seri & 9.1524 & $\mathrm{~cd}$ \\
\hline Latuhalat & 15.1097 & e & Latuhalat & 9.3123 & d \\
\hline
\end{tabular}

Tabel 6. The results of (LSD) test on the differences in the shell length of Monetaria annulus

\begin{tabular}{|c|c|c|c|c|c|}
\hline Station & Average & Notasi & Station & Average & Notasi \\
\hline Hutumuri & 6.4139 & $\mathrm{a}$ & Hutumuri & .727 & $\bar{a}$ \\
\hline Tanjung Tiram & 7.8845 & $\mathrm{~b}$ & Tanjung Tiram & 1.267 & $\mathrm{~b}$ \\
\hline Suli & 8.3768 & $\mathrm{bc}$ & Halong & 1.649 & $\mathrm{c}$ \\
\hline Halong & 8.7012 & $\mathrm{c}$ & Suli & 1.730 & $\mathrm{c}$ \\
\hline Seri & 9.2726 & d & Seri & 2.489 & $\mathrm{~d}$ \\
\hline Latuhalat & 9.6890 & $\mathrm{~d}$ & Latuhalat & 3.006 & $\mathrm{e}$ \\
\hline
\end{tabular}

Table 7. The results of the LSD test, the difference in the length of the blotches of Monetaria annulus

\begin{tabular}{llc} 
Station & Average & Notasi \\
\hline Hutumuri & 9.4696 & $\mathrm{a}$ \\
Tanjung Tiram & 11.9534 & $\mathrm{~b}$ \\
Halong & 12.2368 & $\mathrm{bc}$ \\
Suli & 12.4945 & $\mathrm{bcd}$ \\
Seri & 13.6058 & $\mathrm{~cd}$ \\
Latuhalat & 13.9278 & $\mathrm{~d}$ \\
\hline
\end{tabular}

Table 8. The results of the LSD test, the difference of the width Table 8. The results of the LSD test,

Table 9. The Results of LSD test, the difference in the total weight of Monetaria annulus 
The results of the One-Way-ANOVA analysis on the length and the width of the blotch of $M$. annulus (Table 3 ) is shown the significance value was 0.000 , lower than the $\alpha$ value of $0.05(\mathrm{p}<0.05)$. It means that there was a difference in the length and the width of the blotches of M. annulus at the six observation stations in the coastal waters of Ambon Island. Furthermore, since the results of the One-WayANOVA analysis showed a significant effect, the LSD 0.05 test was performed (Table 7 and Table 8). The results revealed that there was an average difference in the length and width of the blotches of $M$. annulus at the six observation stations in the coastal waters of Ambon Island. However, the average length of $M$. annulus blotches in Tanjung Tiram, Halong and Suli stations is not significant, as at the Halong, Suli and Seri stations; Suli, Seri and Latuhalat. The average width of $M$. annulus blotches at Tanjung Tiram, Suli, and Halong stations are insignificant, as well as at the Halong and Seri stations, and Seri and Latuhalat stations.

Blotches are one of the unique characteristics of Gastropod's family Cypraeidae. On the M. annulus species, the color of the blotches is generally golden yellow and it has ring-shaped form so that this species is generally known as "gold ring cowries". The results of the OneWay-ANOVA analysis (Table 9 and Table 11) revealed that the average length and width of the blotches of the $M$. annulus from each research station were significantly different $(\mathrm{p}<0.005)$, and the results of the LSD test (Table 10 and Table 12) revealed that there was a difference in the average length and width of the blotches of $M$. annulus at each research station. These results (Table 10 and Table 12) indicated that the length and the width of the blotches of $M$. annulus were not significantly different. For the difference in the length of the blotches, Seri station was different from the Latuhalat station, Latuhalat station was different from the Halong station, and Latuhalat station was different from Suli station. For the difference in the width of the blotches, Seri station was different from Latuhalat station, Halong station was different from Tanjung Tiram station, Halong station was different from Suli station, and Tanjung Tiram station was different from Suli station. The insignificant difference in each research station was due to the relatively similar geographical conditions and environmental conditions (Trusell 1997; Madeira et al. 2012). The length and the width of the blotches at Seri Station and Latuhalat station were not significantly different. The insignificant difference in the length and the width of the blotches was also found between Halong stations and Tanjung Tiram stations, between Halong station and Suli station, and between Tanjung Tiram station and Suli station. This is also in line with the results of statistical analysis on the length and width of the shell (Table 3 and Table 5). The difference in the characteristics of $M$. annulus depends on geographical, genetic, age, sex, and environmental condition factor. The variations and the distribution of characteristics are the response to the physical environment where certain species live (Jellison et al. 2016; Laimeheriwa 2017).
The difference in the total weight of Monetaria annulus

The results of the One-Way-ANOVA analysis on the total weight of $M$. annulus (Table 9) is the significance value of about 0.000 , which lower than the $\alpha$ value of 0.05 $(\mathrm{p}<0.05)$. This indicated that there was a difference in the total weight of $M$. annulus at the six observation stations in the coastal waters of Ambon Island. Furthermore, since the results of One-Way-ANOVA showed a significant effect, the LSD 0.05 test was performed (Table 9). LSD test results show that there is a significant average difference in the total weight of $M$. annulus in the coastal waters of Ambon Island, except for Halong and Suli Stations. If the total weight is correlated with the length and the width of the shell of $M$. annulus (Table 3), it can be the longer and the wider the shell of the $M$. annulus is bigger than total weight. Das et al. (2015) explain that the shell diameter, shell height, shell total weight, and weight of an empty shell are influenced by seasonal variations. The shell which measured during the cold season showed the maximum size of shell diameter, shell height, and shell weight, while the shell during the hot season showed the normal/medium size of the shell diameter, shell height, and shell weigh, and the shell which measured during the rainy season showed the minimum size of shell diameter, shell height, and shell weight. In addition, the size, thickness, strength, and calcium content of the shell are influenced by environmental factors such as predation and pollution of heavy metals (Watson et al. 2017; Duquette et al. 2017; Jordaens et al. 2006).

In conclusion, this study was conducted to determine the density and morphology of M. annulus shells at six stations in the coastal waters of the island of Ambon. Six research stations namely Seri, Latuhalat, Halong, Tanjung Tiram, Suli, and Hutumuri were selected for this study. The highest density of $M$. annulus species was found at Tanjung Tiram station, while the lowest species density was found at Latuhalat station. Meanwhile, the results showed that there were differences in shell morphology (e.g. length, width, and height of the shell; the length and width of the blotch; and total weight). Shell morphology differences are influenced by geographical location, coast topography, and type of substrate.

\section{ACKNOWLEDGEMENTS}

The researcher would like to thank the head of the Laboratory of Deep-Sea Research Center, Indonesian Institute of Sciences (LIPI), Ambon, Maluku who had given permission to use the laboratory facilities to examine the samples to determine the morphology characteristics of the shells of $M$. annulus.

\section{REFERENCES}

Amat I, van Alphen JJM, Kacelnik A, Desouhant E, Bernstein C. 2017. Adaptations to different habitats in sexual and asexual populations of parasitoid wasps: a meta-analysis. PeerJ 5: e3699. DOI: $10.7717 /$ peerj.3699. 
Avaca MS, Narvarte M, Martin P, van der Molen S. 2013. Shell shape variation in the Nassariid Buccinanops globulosus in northern Patagonia. Helgol Mar Res 67 (3): 567-577.

Baharuddin N, Basri NB, Syawal NH. 2018. Marine gastropods (Gastropoda; Mollusca) diversity and distribution on intertidal rocky shores of Terengganu, Peninsular Malaysia. AACL Bioflux 11 (4): 1144-1154

Belhiouani H, El-Hadef El-Okki M, Afri-Mehennaoui F-Z, Sahli L. 2019. Terrestrial gastropod diversity, distribution and abundance in areas with and without anthropogenic disturbances, Northeast Algeria. Biodiversitas 20 (1): 243-249.

Bourdeau PE, Butlin RK, Brönmark C, Edgell TC, Hoverman JT, Hollander J. 2015. What can aquatic gastropods tell us about phenotypic plasticity? A review and meta-analysis. Heredity 115 (4): 312-321.

Bula W, Leiwakabessy F, Rumahlatu D. 2017. The Influence of Environmental Factors on the Diversity of Gastropods in Marsegu Island, Maluku. Biosaintifika: J Biol Biol Educ 9 (3): 483-491.

Calosi P, Rastrick SP, Lombardi C, de Guzman HJ, Davidson L, Jahnke M, Giangrande A, Hardege JD, Schulze A, Spicer JI, Gambi MC 2013. Adaptation and acclimatization to ocean acidification in marine ectotherms: an in situ transplant experiment with polychaetes at a shallow CO2 vent system. Phil Trans R Soc Biol Sci 368 (1627): 20120444

Cazenave KR, Zanatta DT. 2016. Environmental drivers of shell shape in a freshwater gastropod from small and large lakes. Freshw Sci 35 (3): 948-957.

Chiu LZ, Fray AC, Weiss LW, Schilling BK, Brown LW, Smith SL. 2003. Post activation potentiation response in athletic and recreationally trained individuals. J Strength Conditioning Res 17 (4): 671-677.

Chiu YW, Lee SC, Chen HC, Chen CA. 2002. Morphometric Analysis of Shell and Operculum Variations in the Viviparid Snail, Cipangopaludina chinensis (Mollusca: Gastropoda), in Taiwan. Zool Stud 41 (3): 321-331.

Crowl TA, Schnell GD. 1990. Factors determining population density and size distribution of a freshwater snail in streams: effects of spatial scale. Oikos 59 (3): 359-367.

Das S, Chakrabortty SK, Roy D, Dolai A. 2015. Morphometric variation of different parameters of snail Segmentina trocoidea, vector of Fasciolopsis buski, in different seasons in a perennial aquatic body at Mourigram, Howrah, West Bengal, India. Intl J Adv Res 3(12): 1584 1592.

Dmitrović D, Savić A, Pešić V. 2016. Discharge, substrate type and temperature as factors affecting gastropod assemblages in springs in Northwestern Bosnia and Herzegovina. Arch Biol Sci 68 (3): $613-$ 621

Duquette A, McClintock JB, Amsler CD, Pérez-Huerta A, Milazzo M, Hall-Spencer JM. 2017. Effects of ocean acidification on the shells of four Mediterranean gastropod species near a $\mathrm{CO}_{2}$ seep. Mar Pollut Bull 124 (2): 917-928.

Gallmetzer I, Haselmair A, Tomasovyc A, Stachowitsch M, Zuschin M. 2017. Responses of molluscan communities to centuries of human impact in the Northern Adriatic Sea. PLoS One: 12 (7): e0180820. DOI: 10.1371/journal.pone.0180820

Gemilang WA, Rahmawan GA, Wisha UJ. 2017. Inner Ambon Bay wate quality based physical and chemical parameters in transition season I. EnviroScientaea 13 (1): 79-90.

Gustafson KD, Kensinger BJ, Bolek MG, Luttbeg B. 2014. Distinct snail (Physa) morphotypes from different habitats converge in shell shape and size under common garden conditions. Evol Ecol Res 16: 77-89.

Hughes L. 2011. Cypraea annulus (Linnaeus, 1758): Gold Ring Cowry. Retrieved from www. gbri.org.au/species/cypraeaannulus.aspx

Foin TC. 1989. Significance of Shell Thickness in Cowries (Mesogastropoda: Cypraeidae). Bull Mar Sci 45 (2): 505-518.

Irawan A, Nganro NR. 2016. Distribution of Seagrasses in inner Ambon Bay. Jurnal Ilmu dan Teknologi Kelautan Tropis 8 (1): 99-114. [Indonesian]

Irie T. 2006. Geographical variation of shell morphology in Cypraea annulus (Gastropoda: Cypraeidae). J Molluscan Stud 72: 31-38.

Irie T, Morimoto N. 2016. Intraspecific variations in shell calcification across thermal windows and within constant temperatures: Experimental study on an intertidal gastropods Monetaria annulus. J Exp Mar Biol Ecol 483: 130-138.

Islami MM. 2015. Distribution of gastropoda and its relation with environmental characteristics in coastal waters of Nusalaut Island,
Central Maluku. Jurnal Ilmu dan Teknologi Kelautan Tropis 7(1): 365-378. [Indonesian]

Jellison BM, Ninokawa AT, Hill TM, Sanford E, Gaylord B. 2016. Ocean acidification alters the response of intertidal snails to a key sea star predator. Proc R Soc B 283: 20160890.

Jordaens K, De Wolf H, Vandecasteele B, Blust R, Backeljau T. 2006. Associations between shell strength, shell morphology and heavy metals in the land snail Cepaea nemoralis (Gastropoda, Helicidae). Sci Total Environ 363 (1-3): 285-293.

Kho DN. 2017. Hubungan antara Faktor Fisik-Kimia Lingkungan dan Substrat dengan Komposisi Jenis Makrozoobenthos Di Daerah Mangrove Pantai Pulau Ambon [The Correlation between physicalchemical environmental factors and substrate with the composition of macrozoobenthos species in the coastal mangrove area of Ambon Island]. [Thesis]. Universitas Pattimura, Ambon. [Indonesian]

Krebs CJ. 1989. Ecological methodology. Harper and Row Publishers Inc., New York, 654 p.

Laimeheriwa BM, Khouw AS, Natan YN, Limmon GV, Hiariey J. 2018a. Phenotypic classification of Moluccas ring cowrie, Cypraea annulus linn., 1758 (Gastropod: Cypraeidae), based on shell meristical. J Aquac Mar Biol 7 (2): 80-90.

Laimeheriwa BM, Bideyesa I, de Gospel M. 2018b. The phenotype expression, taxa level and traits configuration of Moluccas Ring Cowrie, Cypraea Annulus (Gastropod: Cypraeidae) Based on Morphometric Traits data. Int J Oceanogr Aquac 2 (5): 1-25.

Laimeheriwa BM. 2017. Phenetic Relationship Study of Gold Ring Cowry, Cypraea Annulus (Gastropods: Cypraeidae) in Mollucas Islands Based on Shell Morphological. Fish Aquac J 8 (3): 1-15.

Latuconsina H, Nessa MN, Ambo-Rappe R. 2012. The composition of species and structure of seagrass fish community in Tanjung TiramInner Ambon Bay. J Trop Mar Sci Technol 4(1): 35-46.

Limmon GV, Rijoly F, Ongkers OTS, Loupatty SR, Pattikawa JA. 2018. Community structure of reef fish in the southern waters of Ambon Island, eastern Indonesia. AACL Bioflux 11(3): 919-924.

Limmon GV, Rijoly F, Khouw A, Manuputty G, Pattikawa JA. 2017. The Diversity of Grouper (Epinephelinae) in Ambon Island, Maluku, Indonesia. Occas Pap 58: 23-29.

Madeira C, Alves MJ, Mesquita N, Silva SE, Paula J. 2012. Tracing geographical patterns of population differentiation in a widespread mangrove gastropod: genetic and geometric morphometrics surveys along the eastern African coast. Biol J Linn Soc 107 (3): 647-663.

Manullang T, Bakti D, Leidonald R. 2018. Structure of gastropod communities at mangrove ecosystem in Lubuk Kertang village, West Berandan District, Langkat Regency, North Sumatera Province. IOP Conf Ser: Earth Environ Sci 122: 1-6.

Márquez F, Vilela RAN, Lozada M, Bigatti G. 2015. Morphological and behavioral differences in the gastropod Trophon geversianus associated to distinct environmental conditions, as revealed by a multidisciplinary approach. J Sea Res 95: 239-247.

Medeiros C, Caldeira RL, Mendonça CLF, dos Santos Carvalho O, D'ávila S. 2015. Ontogeny and morphological variability of shell in populations of Leptinaria unilamellata (d'Orbigny, 1835) (Mollusca, Pulmonata, Subulinidae). SpringerPlus 4 (191): 1-13.

Meyer CP. 2003. Molecular systematics of cowries (Gastropoda: Cypraeidae) and diversification patterns in the tropics. Biol J Linn Soc 79(3): 401-459.

Minton G, Collins T, Pomilla C, Findlay K, Rosenbaum H, Baldwin R, Brownell RLJr. 2008. Megaptera novaeangliae (Arabian Sea subpopulation). IUCN Red List of Threatened Species. Retrieved from http://www.iucnredlist.org/details/132835

Ode I. 2014. Kandungan alginat rumput laut Sargassum crassifolium dari perairan pantai desa Hutumuri, Kecamatan Leitimur Selatan, Kota Ambon [Alginate content of Sargassum crassifolium seaweed from the coastal waters of Hutumuri village, Leitimur Selatan District, Ambon City]. Jurnal Ilmiah Agribisnis dan Perikanan 6 (3): 47-54. [Indonesian]

Odum EP. 1971. Fundamentals of Ecology. WB Saunders Co., Philadelphia.

Portner HO, Peck LS, Somero G. 2007. Thermal Limits and Adaptation in Marine Antarctic Ectotherms: An Integrative view. Philos Trans R Soc B BiolSci 362: 2233-2258.

Primost MA, Bigatti G, Marquez F. 2015. Shell shape as indicator of pollution in marine gastropods affected by imposex. Mar Freshw Res 67 (12): A-G. DOI: 10.1071/MF15233.

Pyron M, Brown KM. 2015. Introduction to Mollusca and the Class Gastropoda. Elsevier, New York. 
Poutiers JM. 1998. Bivalves (Acephala, Lamellibranchia, Pelecypoda). In: Carpenter KE, Niem VH (eds.). FAO Species Identification Guide for Fishery Purposes; The Living Marine Resources of The Western Central Pacific Volume 1. FAO, Rome.

Quensen JF, Woodruff DS. 2003. Associations between shell morphology and land crab predation in the land snail Cerion. Funct Ecol 11 (4) 464-471.

Rijal M, Rosmawati T, Natsir NA, Amin M, Rochman F, Badwi D, Bahalwan F. 2014. Bioaccumulation Heavy Metals Lead $(\mathrm{Pb})$ and Cadmium (Cd) Seagrass (Enhalus acroides) in Waai and Galala Island Ambon. Intl J Sci: Basic Appl Res 162: 349-356.

Renaud ML. 1976. Observations on the behavior and shell types of Cypraea moneta (Mollusca, Gastropoda) at Enewetak, Marshall Island. Pac Sci 30 (2): 147-158.

Rosin ZM, Kwieciński Z, Lesicki A, Skórka P, Kobak J, Szymańska A, Osiejuk TS, Kałuski T, Jaskulska M, Tryjanowski, P. 2018. Shell colour, temperature, (micro)habitat structure and predator pressure affect the behaviour of Cepaea nemoralis. Sci Nat 105 (35): 1-11.

Rumahlatu D, Huliselan EK, Salmanu SIA. 2018. Spatial and seasonal distribution of cadmium and lead in sediment, water and its response of metal transcription factor-1 in cardinalfish Apogon beauforti. Ilmu Kelautan: Indon J Mar Sci 23(1): 45-54. [Indonesian]

Rumahlatu D, Leiwakabessy F. 2017. Biodiversity of gastropoda in the coastal waters of Ambon Island, Indonesia. AACL Bioflux 10 (2): 285-296.

Rumahlatu D, Huliselan E. 2016. Monitoring mercury (Hg) pollution at Ambon Bay: the use of Apogon beauforti as bioindicator. Ilmu Kelautan: Indon J Mar Sci21 (3): 117-122. [Indonesian]

Rumahlatu D, Gofur A, Sutomo H. 2008. Hubungan faktor fisik-kimia lingkungan dengan keanekaragaman echinodermata pada daerah pasang surut Pantai Kairatu [The Correlation between PhysicalChemical Environmental Factors and Echinoderml Diversity in the Tidal Area of Kairatu Beach]. Jurnal MIPA dan Pembelajarannya 37 (1): 77-85. [Indonesian]

Ruppert EE, Fox RS, Barnes RD. 2004. Invertebrate Zoology. Thomson Learning, Inc, Belmont, CA.

Sahidin A, Zahidah, Hamdani H, Riyantini I, Sewiko R. 2018. The Biodiversity of Gastropods in Karapyak Rocky Shores, Pangandaran Region, West Java Province, Indonesia. Omni-Akuatika 14(2): 79-85.

Saleky D, Etyobudiandi I, Toha HA, Takdir M, Madduppa HH. 2016 Length-weight relationship and population genetics of two marine gastropods species (Turbinidae: Turbo sparverius and Turbo bruneus) in the Bird Seascape Papua, Indonesia. Biodiversitas 17 (1): 208-217.

Sälgeback J, Savazzi E. 2006. Constructional morphology of cerithiform gastropods. Paleontol Res 10 (3): 233-259.

Setyastuti A, Purbiantoro W, Hadiyanto. 2018. Spatial distribution of echinoderms in littoral area of Ambon Island, Eastern Indonesia. Biodiversitas 19 (5): 1919-192.
Silahooy VB, Toha AH, Hakim L, Widodo. 2013. Spatial distribution of Tripneustes gratilla on Ambon Island. J Trop Life Sci 3 (3): 177-181.

Stafford ES, Tyler CL, Leighton LR. 2015. Gastropod shell repair tracks predator abundance. Mar Ecol 36 (4): 1176-1184.

Strong EE, Gargominy O, Ponder WF, Bouchet P. 2008. Global diversity of gastropods (Gastropoda; Mollusca) in freshwater. Hydrobiologia 595: 149-166

Syuja MA, Putro SP, Muhammad F. 2018. Biomonitoring on Integrated Multi-Trophic Aquaculture (IMTA) activities using macrobenthic mollusks on Tembelas Island, Kepulauan Riau Province. J Phys: Conf Ser 1025: 1-6.

Tissot BN. 1984. Multivariate analysis of geographic variation in Cypraea caputserpentis (Gastropoda: Cypraeidae). Theveliger 27 (3): 106119.

Troscianko J, Lown AE, Hughes AE, Stevens M. 2013. Defeating crypsis: detection and learning of camouflage strategies. PLoS One 8 (9): e73733. DOI: 10.1371/journal.pone.0073733.

Tuapattinaja MA, Pattikawa JA, Natan Y. 2014. Community structure of Echinoderms at Tanjung Tiram, inner Ambon bay, Indonesia. AACL Bioflux 7 (5): 351-356.

Tuapattinaya PMJ, Rumahlatu D. 2019. Analysis of Flavonoid Levels of Enhalus acoroides in Different Coastal Waters in Ambon Island, Indonesia. Intl J Appl Biol 3 (1): 70-80.

Trussell GC. 1997. Phenotypic selection in an intertidal snail: effects of a catastrophic storm. Mar Ecol Prog Ser 151: 73-79.

Verhaegen G, Herzog H, Korsch K, Kerth G, Brede M, Haase M. 2019. Testing the adaptive value of gastropod shell morphology to flow: a multidisciplinary approach based on morphometrics, computational fluid dynamics and a flow tank experiment. Zool Lett 5 (5): 1-13.

Vermeij GJ. 2017. Shell features associated with the sand-burying habit in gastropods. J Molluscan Stud 83: 153-160.

Villamora S, Yamamoto T. 2015. Reproductive seasonality of Monetaria annulus (Linnaeus, 1758) (Mollusca: Gastropoda: Cypraeidae) in a temperate area. Molluscan Res 35 (2): 95-101.

Yamamori L, Kato M. 2018. Morphological and ecological adaptation of limpet shaped top shells (Gastropoda: Trochidae: Fossarininae) to wave-swept rock reef habitats. PLoS One 13(8): e0197719.

Yunita F, Leiwakabessy F, Rumahlatu D. 2018. Macrozoobenthos Community Structure in the Coastal Waters of Marsegu Island, Maluku, Indonesia. Intl J Appl Biol 2 (1): 1-11.

Watson SA, Morley SA, Peck LS. 2017. Latitudinal trends in shell production cost from the tropics to the poles. Sci Adv 3 (9): e1701362. DOI: $10.1126 /$ sciadv. 1701362

WoRMS Editorial Board. 2015. World Register of Marine Species. Retrieved from http://www.marinespecies.org/aphia.php?p=taxdetails\&id=216777.

Zhao D, Kong LF, Sasaki T, Li Q. 2019. Shell variations in the gastropod, Monodonta labio, in the North-western Pacific: the important role of temperature in the evolution process. J Mar Biol Assoc U K 99 (7): 1591-1599. 